\title{
PENGEMBANGAN MEDIA KARTU DOMINO MATERI PECAHAN UNTUK BELAJAR MANDIRI SISWA KELAS IV DI MASA NEW NORMAL
}

\author{
Fardillah Zarani Putri ${ }^{1}$, Zetra Hainul ${ }^{\text {Putra*2}^{*} \text {, Munjiatun }}{ }^{3}$ \\ 1,2,3. Universitas Riau, Indonesia. \\ Email: ${ }^{1}$ fardillah.zarani5053@student.unri.ac.id, ${ }^{* 2}$ zetra.hainul.putra@lecturer.unri.ac.id, \\ 3munjiatun@lecturer.unri.ac.id.
}

\begin{abstract}
This study aims to develop domino card media of fractions for independent learning of fourth grade elementary school students in the new normal era. This research was motivated by the lack of learning media that can be used for students, especially when studying independently at home. The development of fraction domino card media was carried out using the Research and Development $(R \& D)$ method with the ADDIE (Analysis, Design, Develop, Implement, Evaluate) development procedure. The pilot subjects of this study consisted of one-to-one trias with 3 students and limited trials with 4 students. This research was conducted in a house of fourth grade students of SDN 147 Pekanbaru in October 2020. The assessment of the validation of fraction domino card media products got a validation percentage score, namely media experts at $95.83 \%$ in the "very valid" category, and from material experts $89.06 \%$ with the "very valid" category. The overall student response to the fraction domino card media that was developed was $90.625 \%$ in the "very good" category and the response of the parents to the fractioned domino card media developed overall got a percentage score of $95.13 \%$ in the "very good" category. The implication of this research is that fraction domino card media has the potential to support students learning from home.
\end{abstract}

Key Words: Domino card media, fractions, mathematics learning, independent learning.

\begin{abstract}
ABSTRAK
Penelitian ini bertujuan untuk mengembangkan media kartu domino pecahan untuk pembelajaran mandiri siswa kelas IV sekolah dasar di era baru normal. Penelitian ini dilatarbelakangi oleh kurangnya media pembelajaran yang dapat digunakan bagi siswa, khususnya pada saat belajar mandiri di rumah. Pengembangan media kartu domino pecahan dilakukan dengan metode Research and Development (R\&D) dengan prosedur pengembangan ADDIE (Analysis, Design, Develop, Implement, Evaluate). Subjek uji coba penelitian ini terdiri dari uji coba satu-satu dengan 3 siswa dan uji coba terbatas dengan 4 siswa. Penelitian ini dilaksanakan di salah satu rumah siswa kelas IV SDN 147 Pekanbaru pada bulan Oktober 2020. Penilaian validasi produk media kartu domino pecahan mendapatkan persentase skor validasi dari ahli media sebesar 95,83\% pada kategori sangat valid, dan dari ahli materi $89.06 \%$ dengan kategori sangat valid. Respon siswa secara keseluruhan terhadap media kartu domino pecahan yang dikembangkan adalah $90,625 \%$ dengan kategori sangat baik, dan respon orang tua terhadap media kartu domino pecahan yang dikembangkan secara keseluruhan mendapat persentase skor 95,13\% pada kategori "sangat baik" kategori. Implikasi dari penelitian ini adalah media kartu domino pecahan berpotensi untuk mendukung pembelajaran siswa dari rumah.
\end{abstract}

Kata kunci : Media kartu domino, pecahan, pembelajaran matematika, pembelajaran mandiri.

\section{PENDAHULUAN}

Pandemi Covid-19 berdampak terhadap pelaksanaan pembelajaran matematika siswa terutama di sekolah dasar. Siswa dituntut untuk belajar mandiri dirumah namun dukungan fasilitas seperti media pembelajaran sangat terbatas. Padahal penggunaan media sangat penting untuk mengembangkan antusias anak dalam belajar. Sebagai contoh, Putra dkk (2011) menggunakan media boneka tangan dalam mendukung siswa kelas satu sekolah dasar meningkatkan kemampuan kombinasi bilangan 10, sedangkan Winanda, Putra, dan Zufriady (2020) menggunakan media tulang napier dalam membantu siswa kelas 3 belajar perkalian bilangan asli. Hasil studi tersebut menunjukkan bahwa pentingnya media dalam mendukung siswa sekolah dasar dalam 
memahami konsep matematika yang abstrak. Selain itu, karakteristik anak SD yang masih senang bermain sehingga membutuhkan dukungan untuk menarik perhatian terhadap apa yang dipelajarinya.

Siswa sekolah dasar masih terikat dengan objek konkret yang dapat ditangkap oleh panca indra berdasarkan perkembangan usia kognitif. Dalam pembelajaran matematika yang abstrak, siswa memerlukan alat bantu berupa media dan alat peraga yang dapat memperjelas apa yang disampaikan oleh guru sehingga lebih cepat dipahami oleh siswa (Heruman, 2013). Pembelajaran matematika di Indonesia memang masih menekankan menghapal rumus-rumus dan menghitung, hal tersebut yang menyebabkan kemampuan pemahaman peserta didik kurang berkembang. Kurangnya kemampuan pemahaman konsep di Indonesia diindikasikan bahwa terjadi permasalahan pada saat proses pembelajaran (Setyabukti dalam Handayani, 2015). Media kartu domino pecahan adalah salah satu media yang menarik dan layak digunakan oleh siswa sekolah dasar (Fitriyahningsih \& Rochmawati, 2014). Melalui media kartu domino pecahan siswa juga tidak merasa bosan karena kartu domino pecahan menyajikan bentuk dan gambargambar yang dapat menarik minat siswa untuk membacanya (Irmawati, 2015, Hestuaji, 2013).

Berdasarkan hasil pengamatan peneliti saat Pengenalan Lapangan Persekolahan (PLP) di SDN 147 Pekanbaru pada kelas IV pada bulan September 2019. Matematika adalah pelajaran yang paling sulit dipahami oleh siswa dikelas IV, salah satu aspek materi yang dianggap sulit yaitu bilangan pecahan. Kesulitan yang dialami siswa dalam menyelesaikan soal pecahan disebabkan oleh kurangnya minat siswa dalam pembelajaran matematika khususnya materi pecahan, motivasi belajar yang rendah dan kemampuan siswa yang lemah dalam pembelajaran matematika (Haniq, 2019). Hal ini terjadi karena guru kurang bisa menanamkan konsep bilangan pecahan secara baik dikarenakan dalam penanaman konsep bilangan pecahan terhadap peserta didik sering kali ketidak tersediaannya media pembelajaran di sekolah (Putra, 2019). Padahal media pembelajaran ini sangat penting bagi seorang guru sebagai sarana menstransfer materi kepada peserta didik dalam memahami konsep.

Memilih media pembelajaran merupakan salah satu hal yang sangat penting dalam proses belajar mengajar, agar tercapainya hasil belajar yang optimal (Anita, 2009; Daryanto, 2013). Banyaknya media bermunculan dan variatif serta sederhana hadir dalam kemasan yang tidak jauh berbeda dengan media canggih. Media sederhana yang sangat mudah digunakan dan tidak membutuhkan teknologi dengan fasilitas yang terbatas salah satunya adalah media kartu domino pecahan. Media kartu domino pecahan adalah sebuah media pembelajaran dalam bentuk kartu bergambar (Setiawan, 2020). Gambar yang ditampilkan dalam kartu tersebut adalah gambaran tangan atau foto yang merupakan rangkaian materi untuk menanamkan konsep pecahan kepada siswa. Cara menggunakan kartu domino ini yaitu dengan mencocokkan gambar yang ada pada kartu dengan kartu yang lainnya.

Media kartu domino memiliki kelebihan dan kelemahan (Indriana, 2011). Kelebihan dari media kartu domino diantaranya: 1) Mudah dibawa kemana-mana karena ukurannya yang seukuran postcard, 2) Praktis dalam membuat dan menggunakannya, sehingga kapanpun anak didik bisa belajar dengan baik menggunakan media ini, 3) Mudah diingat karena kartu ini bergambar yang sangat menarik perhatian, atau berisi huruf atau angka yang simpel dan menarik, sehingga merangsang otak untuk lebih lama mengingat pesan yang ada dalam kartu tersebut, 4) Media ini juga sangat menyenangkan digunakan sebagai media pembelajaran, bahkan bisa digunakan dalam bentuk permainan. Sedangkan kekurangan dari media kartu domino ini diantaranya: 1) Tidak semua bahasan matematika dapat tersampaikan media kartu domino, dan 2) Waktu yang dibutuhkan cukup banyak. 
Media kartu domino yang dikembangkan difokuskan pada pembelajaran pecahan. Materi pecahan dipilih karena merupakan materi yang penting bagi siswa untuk memahami konsep matematika yang lebih tinggi dan abstrak seperti aljabar (Siegler \& Lortie-Forgues, 2017, Putra, 2018). Mengingat luasnya domain materi pecahan, penelitian ini fokus pada pembelajaran tentang pecahan senilai dengan gambar dan model konkret dengan indikator memahami pengertian pecahan senilai dan menganalisis persamaan pecahan senilai dan pecahan tidak senilai.

Tujuan dari pengembangan media kartu domino pecahan ini yaitu untuk membantu siswa belajar mandiri di masa Covid-19 ini. Belajar mendiri dapat diartikan sebagai kegiatan belajar aktif yang didorong oleh niat atau motif untuk menguasai kompetensi tertentu guna mengatasi suatu masalah dan dibangun dengan bekal pengetahuan atau kompetensi yang telah dimiliki (Mudjiman, 2007). Adapun rumusan masalah dari penelitian ini yaitu bagaimana kelayakan media kartu domino pada pembelajaran pecahan dikembangkan untuk belajar mandiri siswa kelas IV sekolah dasar dimasa new normal? Dan bagaimana respon siswa dan orang tua terhadap media kartu domino pecahan yang dikembangkan?

\section{METODE PENELITIAN}

Jenis penelitian yang digunakan yaitu penelitian pengembangan yang dikenal juga dengan Research and Development $(R \& D)$. Research and Development $(R \& D)$ digunakan ketika peneliti ingin menghasilkan produk tertentu dan secara bersamaan menguji efektivitas produk tertentu dalam proses pembelajaran menggunakan media (Sugiyono, 2013). Penelitian media kartu domino yang dikembangkan menggunakan model pengembangan ADDIE yang terdiri dari 5 (lima) tahapan yaitu Analysis (analisis), Design (desain), Development (pengembangan), Implementation (implementasi), dan Evaluation (evaluasi). Penelitian pengembangan media kartu domino materi pecahan di sekolah dasar di uji coba kepada siswa kelas IV SDN 147 Pekanbaru. Penelitian pengembangan ini merupakan salah satu cara dalam memperkaya permainan sehingga dapat memberikan variasi baru, menambah ketersediaan permainan tanpa meninggalkan belajar sehingga mejadikan siswa tertarik untuk mengingat pembelajaran yang sudah dipelajari dengan tampilan berbeda, meningkatkan kerjasama dalam kelompok, menghargai pendapat orang lain dan berintraksi.

Sebagai subjek dalam penelitian ini adalah dua ahli yaitu ahli materi dan ahli media. Subjek uji coba yaitu 7 siswa dan 3 orangtua siswa kelas IV SDN 147 Pekanbaru. Pada uji coba satu satu dilakukan wawancara kepada 3 orang siswa dan pada uji coba terbatas dilakukan kepada 4 orang siswa dengan mengisi angket. Objek dalam penelitian ini yaitu produk media kartu domino. Teknik pengumpulan data dalam penelitian ini yaitu observasi, angket, dan wawancara. Instrumen dari penelitian ini adalah angket validasi yang diberikan kepada validator, wawancara, angket respon siswa dan orang tua.

a. Angket uji validasi produk

Angket uji validasi adalah gambaran penelitian secara umum dari validator mengenai produk pembelajaran. Lembar validasi berfungsi untuk mengetahui kelayakan serta kriteria kesesuaian produk yang telah dirancang oleh peneliti. Angket uji validasi produk diadaptasi dari Rendana (2018) dan disajikan dalam tabel 1.

Tabel 1. Kisi-kisi Angket Ahli Materi dan Ahli Media

\begin{tabular}{ccc}
\hline No & Aspek & \multicolumn{1}{c}{ Indikator } \\
\hline 1 & Kelayakan isi & $\begin{array}{l}\text { Kesesuaian materi pembelajaran } \\
\text { Mendorong rasa keingintahuan }\end{array}$ \\
\hline
\end{tabular}




\begin{tabular}{|c|c|c|c|}
\hline & \multicolumn{2}{|c|}{$\begin{array}{l}\text { JURNAL ILMIAH AQUINAS } \\
\text { http://ejournal.ust.ac.id/index.php/Aquinas/index }\end{array}$} & $\begin{array}{l}\text { p-ISSN: } 2615-7683 \\
\text { e-ISSN: } 2714-6472\end{array}$ \\
\hline 2 & Penggunaan & $\begin{array}{l}\text { Media mudah digunakan } \\
\text { Bersifat interaktif }\end{array}$ & \\
\hline 3 & Tampilan & $\begin{array}{l}\text { Kejelasan tampilan media pembelajaran } \\
\text { Kemenarikan media pembelajaran } \\
\text { Kesesuaian media pembelajaran } \\
\text { pembelajaran } \\
\text { Kejelasan gambar } \\
\text { Ukuran gambar } \\
\text { Ketepatan penempatan gambar } \\
\text { Penggunaan huruf } \\
\text { Tata letak }\end{array}$ & dengan \\
\hline 4 & Penyajian & $\begin{array}{l}\text { Keawetan media } \\
\text { Media dirancang secara praktis }\end{array}$ & \\
\hline
\end{tabular}

b. Angket uji coba produk/ angket respon

Angket uji coba produk adalah teknik pengumpulan data yang diisi oleh responden siswa yang diisi setelah media digunakan atau diuji coba. Pengukuran angket yang digunakan dalam penelitian ini adalah dengan skala likert. Skala likert merupakan skala yang digunakan untuk mengukur sikap, pendapat, dan persepsi seseorang atau sekelompok orang tentang fenomena sosial (Sugiyono, 2015). Angket uji coba produk respon siswa dan orang tua diadaptasi dari Rendana (2018) yang disajikan pada tabel 2 .

Tabel 2. kisi-kisi angket respon siswa dan orang tua

\begin{tabular}{|c|c|c|}
\hline No & Aspek & Pernyataan \\
\hline 1 & $\begin{array}{l}\text { Efektifitas } \\
\text { media }\end{array}$ & $\begin{array}{l}\text { Kemudahan isi media untuk dipahami dan dimengerti } \\
\text { Dapat membantu peserta didik dalam memahami materi } \\
\text { pecahan }\end{array}$ \\
\hline 2 & Aktifitas belajar & Membuat siswa belajar mandiri \\
\hline & siswa & $\begin{array}{l}\text { Membantu meningkatkan pemahaman siswa tentang materi } \\
\text { pecahan }\end{array}$ \\
\hline 3 & $\begin{array}{l}\text { Motivasi belajar } \\
\text { siswa }\end{array}$ & $\begin{array}{l}\text { Penyajian warna, angka dan gambar } \\
\text { Merangsang rasa ingin tahu siswa } \\
\text { Membuat siswa lebih tertarik untuk belajar materi pecahan } \\
\text { Meningkatkan minat siswa untuk belajar }\end{array}$ \\
\hline
\end{tabular}

c. Wawancara

Peneliti melakukan wawancara kepada 3 orang siswa kelas IV SDN 147 Pekanbaru. Wawancara yang dilakukan adalah wawancara tidak terstuktur. Instrumen wawancara dapat dilihat pada tabel 3. Wawancara dilakukan untuk mengetahui masukan dan pendapat dari responden mengenai media yang dikembangkan.

Tabel 3. Soal wawancara siswa

\begin{tabular}{ll}
\hline No & \multicolumn{1}{c}{ Pertanyaan } \\
\hline 1. & Berikan pendapat anda tentang media kartu domino pecahan? \\
2. & Bagaimana perasaan setelah bermain? \\
3. & Apa kesulitan yang dirasakan ketika bermain? \\
4. & Apakah anda lebih memahami materi dengan menggunakan kartu domino \\
& pecahan dibandingkan dengan pembelajaran biasanya?
\end{tabular}


5. Apa saran anda untuk perbaikan media?

\section{HASIL DAN PEMBAHASAN \\ HASIL}

Penelitian pengembangan media kartu domino materi pecahan menggunakan model pengembangan ADDIE terdiri dari 5 (lima) tahap yaitu Analysis (analisis), Design (desain), Development (pengembangan), Implementation (implementasi) dan Evaluation (evaluasi). Tahapan-tahapan hasil pelaksanaan penelitian pengembangan ini diuraikan sebagai berikut:

1. Tahap Analysis (Analisis)

Tahap analisis berguna untuk menentukan dan mendefinisikan kebutuhankebutuhan didalam proses pembelajaran serta mengumpulkan berbagai informasi yang berkaitan dengan produk yang akan dikembangkan. Pada tahapan ini peneliti melakukan analisis peserta didik dan analisis materi.

a. Analisis peserta didik: Analisis karakteristik peserta didik dilakukan untuk mengetahui keterampilan gaya belajar, dan sikap peserta didik untuk siap melakukan proses pembelajaran. Siswa SD menyenangi pembelajaran yang menyenangkan dan tidak terlalu kaku. Oleh karena itu, dengan media kartu domino pecahan, diharapkan siswa lebih menyenangi pembelajaran dan dapat meningkatkan minat siswa untuk menggali informasi yang terdapat didalam kartu domino pecahan. Analisis ini dilakukan dengan observasi pembelajaran dikelas dan diluar kelas yang dilakukan semasa pengenalan lapangan persekolahan (PLP). Berdasarkan hasil observasi, karakteristik siswa kelas IV SDN 147 Pekanbaru adalah senang bermain, aktif bergerak dan senang mempelajari hal baru dan memiliki rasa keingintahuan yang tinggi.

b. Analisis materi dilakukan dengan cara mengidentifikasi materi utama yang akan digunakan atau dipilih, mengumpulkan materi dan memilih materi yang relevan dan menyusunnya kembali secara sistematis. Materi yang diambil pada pelajaran 1 tentang pecahan. Materi pembelajaran yan dipilih disesuaikan dengan pembelajaran yang sedang berjalan. Dalam pembelajaran ini mempelajari tentang mengenal pecahan dan pecahan senilai. Angka dan gambar pada kartu domino pecahan dibuat sesuai dengan yang dipelajari oleh siswa agar mudah dipahami oleh siswa.

2. Tahap Design (Perancangan)

Tahap kedua ini adalah perancangan. Tahap perancangan ini bertujuan untuk merancang penyajian suatu media kartu domino yang akan digunakan.

a. Perancangan desain produk

Peneliti mulai membuat konsep media kartu domino pecahan dan petunjuk penggunaan yang akan didesain. Berdasarkan materi yang diajarkan, peneliti mulai medesain kartu domino berukuran $7 \mathrm{~cm} \mathrm{x} 3 \mathrm{~cm}$ menggunakan software microsoft office word 2013. Setelah ukuran disesuaikan kemudian menentukan warna background dan memasukkan angka dan gambar pecahan. Untuk salah satu ruas berisikan angka dan ruas lainnya berisikan gambar pecahan. Kartu domino pecahan ini terdiri dari 28 kartu yang dicetak dengan kertas paper art tebal 210 gr kemudian dilaminating agar media awet dapat digunakan kembali. Kelengkapan membuat media kartu domino sebagai berikut :

1) Menyiapkan sumber buku (buku matematika kelas IV SD).

2) Mengidentifikasi materi (dari buku matematika kelas IV SD terfokus pada materi pecahan).

3) Font yang digunakan pada kartu domino pecahan adalah cambria math dan gambar pecahan yang dibuat dengan aplikasi paint. 
Kartu domino terdiri dari 2 (dua) sisi. Salah satu sisinya berisi angka pecahan dan sisi lainnya berisi gambar pecahan. Jumlah kartu domino pecahan adalah 28 kartu.

b. Draft awal kartu domino pecahan

Pada tahap ini dilakukan pembuatan kartu domino pecahan, pewarnaan kartu, penempatan gambar dan angka pada kartu. Pembuatan draft awal kartu domino pecahan dilakukan dengan memilih ukuran kartu domino pecahan. Dalam penelitian ini penulis menggunakan aplikasi microsoft word 2013 kemudian dengan tool insert table. Gambar draft awal kartu domino disajikan pada gambar 1.

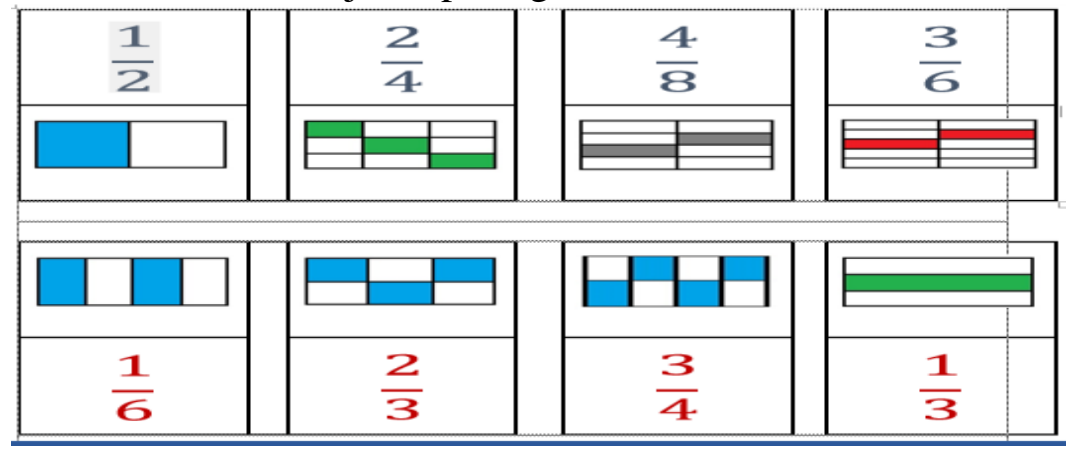

Gambar 1. Gambar draft awal kartu domino

Setelah menentukan ukuran kartu domino pecahan, penulis menempatkan angka dan gambar pecahan. Setelah itu melakukan pewarnaan pada background. Untuk melakukan pewarnaan background pada software microsoft word 2013. Pewarnaan dilakukan dengan perangkat komputer atau laptop pada menu aplikasi yang tersedia agar dapat menghasilkan warna yang lebih bagus.

Tahap awal dengan menentukan ukuran kartu domino pecahan yaitu $7 \mathrm{~cm} \times 3 \mathrm{~cm}$, kemudian penempatan gambar pecahan dan bilangan pecahan sesuai dengan susunan yang sudah ditentukan, lalu memberikan pewarnaan pada background, dan tahap akhir adalah mencetak kartu domino pecahan dengan kertas art paper 210 gr dan dilaminating agar media awet dapat digunakan kembali.

2. Tahap Development (Pengembangan)

Tahap pengembangan ini bertujuan untuk menghasilkan produk media kartu domino pecahan yang sudah direvisi berdasarkan masukan ahli media dan ahli materi. Validasi ahli berfungsi untuk memvalidasi kartu domino pecahan sebelum dilakukan uji coba, hasil validasi akan digunakan untuk melakukan revisi produk awal, produk kartu domino pecahan yang telah disusun kemudian akan dinilai oleh dosen ahli media dan dosen ahli materi, sehingga dapat diketahui apakah media kartu domino pecahan tersebut layak diterapkan atau tidak. Hasil dari validasi ini digunakan sebagai bahan perbaikan untuk kesempurnaan produk media kartu domino pecahan yang dikembangkan.

a. Validasi Produk, setelah tahap perancangan selesai maka dilakukan tahap validasi produk. Validasi media kartu domino dilakukan dengan 2 validator yaitu: 1 ahli media, dan 1 ahli materi. Proses pengembangan media kartu domino dilakukan dengan saran dan masukan oleh validator. Hasil validasi ahli media disajikan pada tabel 4.

Tabel 4. Data Validasi Ahli Media.

\begin{tabular}{llll}
\hline No & $\begin{array}{l}\text { Aspek } \\
\text { Penilaian }\end{array}$ & $\begin{array}{l}\text { Validasi I } \\
\text { Persentase }\end{array}$ & Kategori \\
\hline 1 & Tampilan & $91,66 \%$ & Sangat Valid \\
2 & Penyajian & $100 \%$ & Sangat Valid \\
3 & Kelayakan Isi & $91,66 \%$ & Sangat Valid \\
\hline
\end{tabular}




\begin{tabular}{lll}
\hline \hline $4 \quad$ Penggunaan & $100 \%$ & Sangat Valid \\
\hline $\begin{array}{l}\text { Rata-rata } \\
\text { Persentase }\end{array}$ & $\mathbf{9 5 , 8 3 \%}$ & Sangat Valid \\
\hline
\end{tabular}

Hasil dari tabel 4 menunjukkan bahwa rata-rata skor penilaian dari validator yaitu 95,83\% dengan memiliki kategori sangat valid dan skor terendah 91,66\% pada kategori sangat valid serta skor tertinggi $100 \%$ pada kategori sangat valid. Hasil validasi materi disajikan pada tabel 5 .

Tabel 5. Data Validasi Ahli Materi

\begin{tabular}{llll}
\hline No & $\begin{array}{l}\text { Aspek } \\
\text { Penilaian }\end{array}$ & $\begin{array}{l}\text { Validasi II } \\
\text { Persentase }\end{array}$ & Kategori \\
\hline 1 & Tampilan & $91,66 \%$ & Sangat Valid \\
2 & Penyajian & $93,75 \%$ & Sangat Valid \\
3 & Kelayakan Isi & $83,33 \%$ & Sangat Valid \\
4 & Penggunaan & $87,5 \%$ & Sangat Valid \\
\hline $\begin{array}{l}\text { Rata-rata } \\
\text { Persentase }\end{array}$ & $\mathbf{8 9 , 0 6 \%}$ & Sangat Valid \\
\hline
\end{tabular}

Hasil penilaian validasi ahli materi memiliki skor rata-rata skor penilaian validator materi yaitu $89,06 \%$ dan dikategorikan sangat valid untuk digunakan, dengan skor terendah $83,33 \%$ pada kategori sangat valid dengan skor tertinggi $93,75 \%$.

Media pembelajaran kartu domino pecahan dapat digunakan dengan revisi sesuai saran validator media dan validator materi (Tabel 6).

Tabel 6. Saran dan Perbaikan oleh Validator

\begin{tabular}{|c|c|c|}
\hline No & $\begin{array}{l}\text { Bidang } \\
\text { Keahlian }\end{array}$ & Saran Perbaikan \\
\hline 1 & Ahli Media & $\begin{array}{l}\text { Sebaiknya gambar untuk pecahannya tidak satu macam. } \\
\text { Warnanya tidak menarik. } \\
\text { Sebaiknya kartu domino dibuat lebih tahan lama } \\
\text { setidaknya dilaminating. } \\
\text { Aturan mainnya tidak jelas, seharusnya disebutkan } \\
\text { berapa jumlah kartu dan berapa dibagikan. } \\
\text { Aturan pemasangan harus dijelaskan bahwa pasangan } \\
\text { gambar harus angka }\end{array}$ \\
\hline
\end{tabular}

2 Ahli Materi Posisi angka tolong diperhatikan letaknya. Pastikan berada di tengah-tengah.

Warna gambar pastikan terlihat jelas.

Petunjuk perlu diperjelas, terutama pada nomor 6 pada kartu petunjuk guru dan nomor 4 pada kartu petunjuk siswa. Yang pertama kali keluar biasanya adalah kartu yg nilaianya sama, misalnya gambar $1 / 2$ dan angka $1 / 2$. Sedangkan untuk permainan ke-2, yang dulu mulai adalah pemenang pada permainan sebelumnya.

Alangkah baiknya dituliskan tujuan pembelajaran pada pedoman cara memainkan kartu domino.

Perlu dituliskan materi apa yang akan dipelajari di kertas panduan permainan 
Perlu diperjelas lagi terutama pada peraturan siapa yg mulai duluan. Background pada petunjuk terlalu rame.

Peneliti selanjutnya melakukan revisi sesuai saran semua validator. Proses ini bertujuan agar produk yang dihasilkan mudah dipahami oleh siswa sekolah dasar, baik dari segi tampilan maupun permasalahan matematika yang diberikan. Gambar 2 merupakan salah satu contoh hasil perbaikan terhadap kartu domino pecahan.
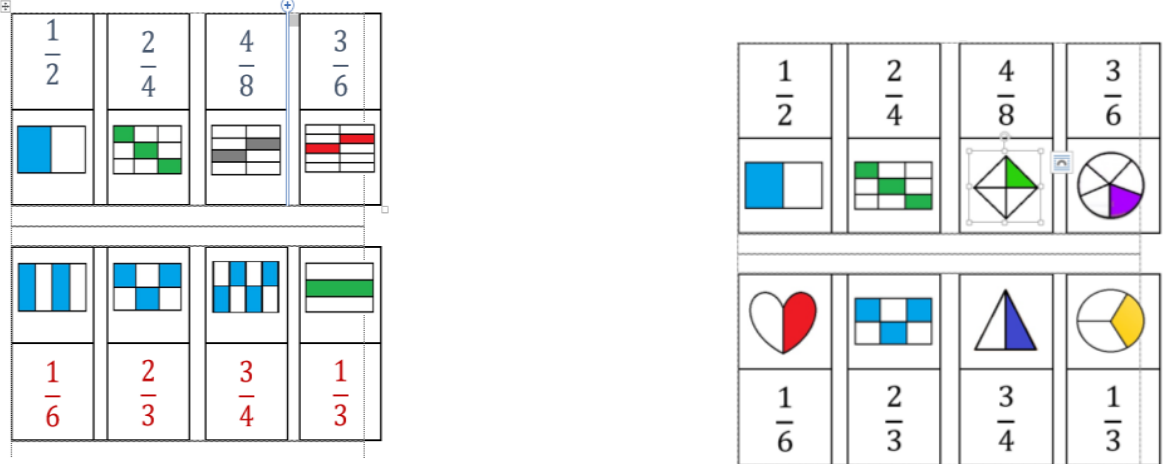

Sebelum Revisi

Sesudah Revisi

\section{Gambar 2. Contoh hasil perbaikan pada kartu domino pecahan}

Tampilan gambar untuk pecahannya hanya satu macam saja, dan warnanya kurang menarik dan kurang jelas sebelum revisi (Gambar 3). Setelah revisi gambar untuk pecahannya sudah dibuat bervariasi dengan warna yang menarik dan tampak lebih jelas.

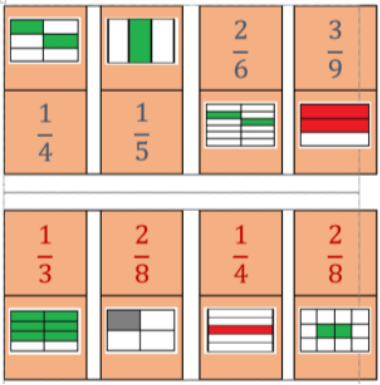

Sebelum Revisi

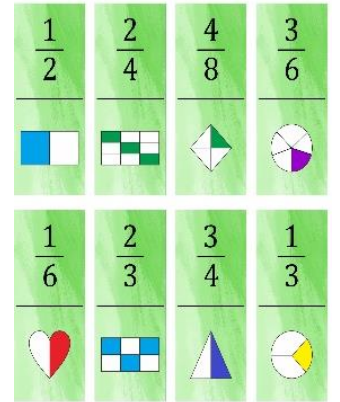

Sesudah Revisi

Gambar 3. Salah satu hasil perbaikan pada kartu domino pecahan

Gambar 3 mengalami perbaikan pada pewarnaan background dan warna angka. Sebelum revisi warna background dan angka tidak begitu jelas, setelah revisi warna background dan angka sudah jelas dan warna gambar pecahan terlihat jelas. 


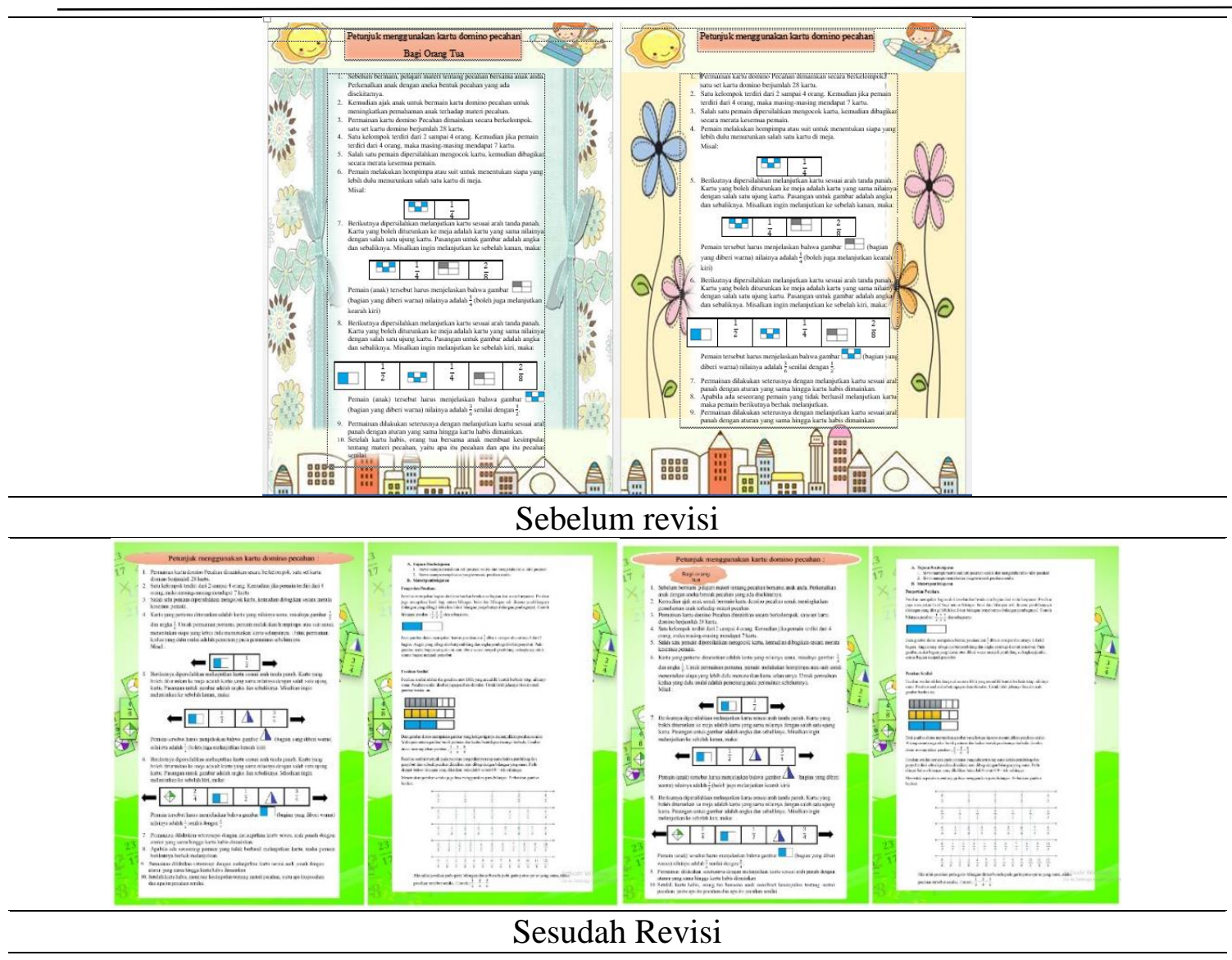

Gambar 4. Perbaikan panduan penggunaan kartu domino pecahan

Gambar 4 terlihat bahwa aturan permainannya masih kurang jelas, background nya juga terlalu ramai dan belum memuat materi serta tujuan yang akan dipelajari. Setelah direvisi petunjuk atau aturan permainannya lebih diperjelas, background pada panduan sudah disederhanakan dan sudah memuat materi serta tujuan yang akan dipelajari.

4. Tahap Implement (Implementasi)

Setelah divalidasi, produk tersebut dilakukan evaluasi satu-satu pada 3 siswa kelas IV dan dimainkan sebanyak 3 kali, pada uji coba satu-satu produk kartu domino pecahan dimainkan oleh 3 orang siswa dan dipandu oleh peneliti dan orang tua siswa. Mereka bermain dengan cara berkelompok terdiri dari 3 orang dan masing-masing mendapatkan 9 kartu. 1 kartu yang tersisa sebagai kartu yang turun pertama kali untuk dilanjutkan oleh pemain. Kemudian siswa melakukan hompimpa untuk menentukan siapa yang menurunkan kartu terlebih dahulu, selanjutnya siswa mencocokkan kartu sampai kartu habis.

Pada saat bermain terlihat ketiga siswa tersebut sangat senang bermainnya walaupun ada beberapa kali kesalahan dalam menentukan hitungan pecahan senilai. Setelah mereka bermain peneliti mewawancarai ketiga siswa mengenai produk kartu domino yang sudah dimainkan. Mereka mengatakan bahwa mereka sangat tertarik dengan media kartu domino pecahan. Terkait dengan pendapat mereka tentang media, mereka mengatakan bahwa mereka lebih mudah belajar dengan media kartu domino pecahan dan mereka sangat senang saat belajar dengan media kartu domino pecahan. Hal ini salah satunya diungkapkan oleh siswa A yang mengatakan ketika ditanya bagaimana pendapat anda tentang media, ia menjawab sangat menyenangkan.

Siswa B ketika ditanya apakah ada kesulitan saat menggunakan media, ia mengatakan bahwa tidak ada kesulitan. Hal ini mengindikasikan bahwa media kartu domino pecahan mudah dipahami oleh siswa. Mereka lebih mudah memahami materi 
dengan menggunakan media dibandingkan dengan pembelajaran biasaya. Seperti yang diuangkapkan oleh siswa $\mathrm{C}$, ia mengatakan bahwa ia lebih memahami materi saat belajar dengan media kartu domino pecahan. Untuk saran perbaikan media menurut ketiga siswa media kartu domino pecahan sudah bagus sesuai dengan minat siswa dan tidak ada saran perbaikan. Selanjutnya peneliti melakukan uji coba terbatas pada 4 siswa kelas IV SDN 147 Pekanbaru. Uji coba terbatas dilakukan dengan menggunakan produk. Produk dimainkan sesuai cara dan peraturan yang berlaku yaitu siswa bermain dalam kelompok. Setelah produk selesai dimainkan, peneliti membagikan angket respon siswa untuk mendapatkan respon terhadap produk yang telah dimainkan.

5. Tahap Evaluate (Evaluasi)

Tahap ini dilakukan dengan metode formatif. Tahap evaluasi dilakukan untuk menilai kualitas produk yang dikembangkan dan proses pengembangan produk itu sendiri. Pada uji satu satu, dilakukan wawancara kepada siswa kelas IV mengenai produk yang dikembangkan. Melalui wawancara tersebut diperoleh informasi bahwa siswa sangat senang dalam bermain karena dapat mengingat pembelajaran dengan menggunakan media kartu domino. Produk ini juga memiliki tampilan yang menarik dan materi yang dimuat dapat dimengerti dengan baik. Siswa dapat memahami peraturan permainan yang diberikan. Sedangkan pada uji coba terbatas peneliti memberikan angket respon siswa kepada siswa setelah menggunakan media kartu domino. Hasil respon siswa disajikan pada tabel 7.

Tabel 7. Angket respon siswa

\begin{tabular}{clll}
\hline No & \multicolumn{1}{c}{ Aspek } & \multicolumn{1}{c}{ Persentase } & \multicolumn{1}{c}{ Katagori } \\
\hline 1. & Efektivitas Media & $93,75 \%$ & Sangat baik \\
\hline 2. & Aktivitas Belajar Siswa & $93,75 \%$ & Sangat baik \\
\hline 3. & Motivasi Belajar Siswa & $84,375 \%$ & Sangat baik \\
\hline Rata-rata skor respon siswa & $\mathbf{9 0 , 6 2 5 \%}$ & Sangat baik \\
\hline
\end{tabular}

Berdasarkan hasil data respon siswa terhadap produk kartu domino pecahan guna merefleksi materi pembelajaran matematika materi mengenal pecahan dan pecahan senilai yang dikembangkan oleh peneliti diperoleh rata-rata skor 90,625\% dengan kategori sangat baik. Berdasarkan hasil tersebut secara keseluruhan produk kartu domino pecahan yang dikembangkan oleh peneliti mendapatkan respon yang sangat baik dari siswa yang menggunakan produk ini.

Selanjutnya peneliti juga memberikan angket kepada 3 orang tua siswa. Melalui angket tersebut diketahui bahwa media kartu domino pecahan merupakan produk baru bagi orang tua siswa yang dapat membantu siswa saat belajar dirumah terutama dalam masa new normal ini. Orang tua siswa lebih mudah menyampaikan materi dengan menggunakan media dan siswa lebih memahami tentang materi yang diajarkan, Informasi tersebut didapatkan dari angket respon orang tua siswa yang diberikan. Hasil tanggapan orang tua siswa dapat dilihat pada tabel 8 di bawah ini:

\section{Tabel 8. Data Tanggapan Orang Tua Siswa}

\begin{tabular}{clll}
\hline No & \multicolumn{1}{c}{ Aspek } & \multicolumn{1}{c}{ Persentase } & \multicolumn{1}{c}{ Katagori } \\
\hline 1. & Efektivitas Media & $95,83 \%$ & Sangat baik \\
\hline 2. & Aktivitas Belajar Siswa & $95,83 \%$ & Sangat baik \\
\hline 3. & Motivasi Belajar Siswa & $93,75 \%$ & Sangat baik \\
\hline Rata-rata skor respon siswa & $\mathbf{9 5 , 1 3 \%}$ & Sangat baik \\
\hline
\end{tabular}

Berdasarkan hasil data respon orang tua siswa terhadap produk kartu domino pecahan guna merefleksi materi pembelajaran matematika materi mengenal pecahan 
dan pecahan senilai yang dikembangkan oleh peneliti diperoleh rata-rata skor $95,13 \%$ dengan kategori sangat baik. Berdasarkan hasil tersebut secara keseluruhan produk kartu domino pecahan yang dikembangkan oleh peneliti mendapatkan respon yang sangat baik dari orang tua siswa yang menggunakan produk ini.

\section{PEMBAHASAN}

Pengembangan media kartu domino pecahan sebagai produk permainan baru di Sekolah Dasar dilakukan sesuai dengan prosedur pengembangan model ADDIE. Model ADDIE terdiri dari lima tahap yaitu: 1) Analyze (analisis); 2) Design (perancangan); 3) Development (pengembangan); 4) Implementation (pelaksanaan); dan 5) Evaluation (penilaian), Pengembangan media kartu domino pecahan dimulai dari tahap analisis yang terdiri dari analisis peserta didik, dan materi. Analisis peserta didik sangat penting dilakukan pada awal perencanaan. Analisis peserta didik dilakukan dengan cara mengamati karakteristik peserta didik. Agar media yang akan dikembangkan sesuai dengan minat siswa. Permainan adalah modal awal bagi pembinaan kecerdasan dan mental serta emosional anak, sehingga cara dan pola bermain yang diterapkan dalam pembelajaran akan memiliki efek yang positif bagi pertumbuhan kecerdasan dan emosional anak (Erfayliana, 2016). Analisis materi dilakukan dengan cara mengidentifikasi materi utama yang akan digunakan atau dipilih, mengumpulkan materi dan memilih materi yang relevan dan menyusun nya kembali secara sistematis, Pendidikan berfungsi membantu peserta didik dalam sebuah pengembangan potensi, baik bagi dirinya dan juga orang lain atau lingkungan lainya.

Materi yang dipilih untuk produk yaitu "Pecahan" yang diambil dari buku matematika pegangan guru dan buku siswa kelas IV SD pada Bab pecahan sub bab pengertian pecahan dan pecahan senilai. Kemudian pada tahap desain peneliti mulai merancang media sesuai dengan tujuan yang telah ditetapkan. Produk terdiri dari 1 set kartu domino pecahan, panduan secara umum dan panduan bagi orang tua. Pada panduan terdapat petunjuk menggunakan media, tujuan pembelajaran dan materi yang diajarkan.

Tahap pengembangan dilakukan mulai September 2020. Untuk mengetahui kelayakan produk maka dilakukan validasi kelayakan oleh 2 orang validator yang terdiri dari seorang validator ahli media dan satu orang validator ahli materi. Setelah divalidasi, peneliti melakukan revisi instrumen sesuai saran dari validator sehingga instrumen layak untuk menilai produk kartu domino pecahan untuk di uji cobakan secara terbatas pada 4 orang siswa kelas IV. Hasil validasi dari validator menunjukkan bahwa berada pada kategori sangat valid. Pada validator ahli materi yang rata-rata persentase $89,06 \%$ dengan kategori sangat valid dan validator ahli media yang rata-rata persentase $95,83 \%$ dengan kategori sangat valid. Pada tahap pengembangan kerangka yang masih konseptual tersebut direalisasikan menjadi produk yang siap diimplementasikan (Mulyatiningsih, 2014).

Pada tahap implementasi dilakukan uji coba satu satu kepada 3 orang siswa dengan wawancara dan melakukan uji coba terbatas kepada 4 orang siswa. Pada tahap ini implementasi produk dilakukan pada situasi nyata yaitu di kelas (Mulyatiningsih, 2014). Dengan keadaan saat ini yang tidak baik karena adanya wabah covid-19, uji coba satusatu dan uji coba terbatas dilakukan dirumah salah satu siswa kelas IV SDN 147 Pekanbaru. Siswa sangat senang dan bersemangat ketika bermain atau memperagakan produk. Hal ini dapat dilihat dari reaksi dan respon siswa karena dengan bermain kartu domino pecahan merupakan yang pertama mereka alami. Adanya kartu domino pecahan lebih menarik siswa untuk mengingat dan memahami pembelajaran yang sudah dipelajari dan membuat siswa sangat bersemangat karna siswa pada tingkat sekolah dasar memiliki karakteristik senang bermain, senang 
bergerak, senang bekerja dalam kelompok, dan senang merasakan atau melakukan atau memperagakan sesuatu secara langsung (Indriani, 2014).

Lalu untuk mengetahui tingkat kepahaman siswa memahami materi dalam permainan kartu domino pecahan, siswa bersama orang tua membuat kesimpulan tentang materi pengertian pecahan dan pecahan senilai sesuai dengan panduan orang tua dan mendapat hasil yang baik. Pada tahap evaluasi didapati respon siswa terhadap media kartu domino pecahan yaitu 90,625\% dengan kategori sangat baik dan respon orang tua terhadap media kartu domino pecahan yaitu 95,13\% dengan kategori sangat baik. Hal ini sejalan dengan hasil penelitian bahwa penggunaan media (media blok) pada pembelajaran pecahan dapat mempengaruhi minat belajar siswa (Lastri, 2019).

Jadi media kartu domino pecahan yang peneliti kembangkan bukanlah seperti kartu domino yang biasa dipergunakan. Kartu domino yang tersebar dimasyarakat memiliki dua bagian utama, dimana setiap bagiannya memuat simbol-simbol yang sama hanya jumlahnya yang berbeda. Kartu domino pecahan ini tentu berbeda dilihat dari konten dan desainnya. Konten dalam kartu domino pecahan ini memuat pecahan biasa dan gambar pecahan. Desainnya juga berbeda kartu domino ini lebih bervariasi dan berwarna sehingga lebih menarik perhatian pesert didik. Hal tersebut selaras dengan kemampuan warna dalam menciptakan impresi secara psikologis bagi peserta didik, warna-warna itu bukanlah yang hanya dapat diamati saja, warna juga dapat berpengaruh terhadap perilaku, serta berperan dalam penilaian estetis (Mansyur, 2007).

Media kartu domino pecahan ini agar siswa lebih memahami dan mudah mengingat materi yang sudah diajarkan. Angka dan gambar pecahan dalam kartu domino pecahan menggunakan materi yang sederhana sehingga anak mudah memahaminya, peneliti berharap setelah adanya pengembangan kartu domino pecahan ini agar menjadi sebuah ide dalam penggunaan media pembelajaran dan meningkatkan variasi media pembelajaran khususnya mata pelajaran matematika. Langkah terakhir yang dilakukan adalah evaluasi atau penilaian terakhir. Berdasarkan hasil tersebut, pengembangan produk media kartu domino pecahan kelas IV SD sangat baik digunakan.

\section{PENUTUP}

Berdasarkan hasil penelitian dan pembahasan, maka hasil pengembangan produk akhir berupa media kartu domino materi pecahan untuk belajar mandiri siswa kelas IV SDN 147 Pekanbaru di masa new normal dapat disimpulkan bahwa penilaian validator oleh validator ahli diperoleh bahwa media pembelajaran kartu domino pecahan untuk belajar mandiri siswa kelas IV yang dikembangkan oleh peneliti dilihat dari validasi ahli media dengan rata-rata 95,83\% kategori sangat valid dan validasi ahli materi dengan rata-rata 89,06\% kategori sangat valid, maka layak untuk diuji cobakan. Respon siswa terhadap produk media kartu domino pecahan secara keseluruhan mendapat skor persentase 90,625\% pada kategori Sangat Baik. Respon orang tua siswa terhadap produk media kartu domino pecahan mendapat skor persentase $95,13 \%$ pada kategori Sangat Baik.

Dengan demikian, dapat disimpulkan bahwa media kartu domino pecahan yang dikembangkan layak untuk digunakan siswa disekolah.

Mengacu pada hasil penelitian, peneliti akan memberikan beberapa rekomendasi yang dapat dijadikan sebagai masukan bagi pihak yang terkait. Bagi peneliti selanjutnya dapat menjadikan penelitian ini sebagai pedoman dan referensi untuk kesempurnaan penelitian yang akan datang. Bagi sekolah, dengan adanya pengembangan produk kartu domino pecahan sekolah dapat mengaplikasikan produk ini kedalam kegiatan diluar pembelajaran siswa dengan bermain di Sekolah Dasar. Bagi guru, agar dapat menggunakan media ini sebagai salah satu sumber informasi dalam mengajarkan materi pecahan disekolah dasar. Bagi siswa, supaya dapat mengunakan 
media pembelajaran ini sebagai sumber belajar. Bagi Orang Tua, pengembangan produk kartu domino pecahan ini dapat diaplikasikan dalam kegiatan belajar mandiri dirumah untuk memudahkan siswa memahami materi pecahan khususnya pengertian pecahan dan pecahan senilai.

\section{DAFTAR PUSTAKA}

Anitah, S. (2009). Media Pembelajaran. Surakarta: UNS Press.

Daryanto. (2013). Media Pembelajaran. Yogyakarta: Gava Media.

Erfayliana. (2016). Aktivitas Bermain dan Perkembangan Jasmani Anak . Terampil jurnal Pendidikan dan pembelajaran Dasar(3), 145-58.

Fitriyahningsih, R., \& Rochmawati. (2014). Pengembangan Kartu Domino Sebagai Media Pembelajaran Akuntansi Pada Materi Ayat Jurnal Penyesuaian. Jurnal Pendidikan Akuntansi, Vol.2, No.2.

Handayani, H. (2015). Pengaruh Pembelajran Kontekstual Terhadap Kemampuan Pemahaman dan Representasi Matematika Siswa Sekolah Dasar. Jurnal Pendidikan Guru Sekolah Dasar, 1(1), 142-149.

Haniq, U. (2019). Kesulitan Siswa Dalam Menyelesaikan Soal Matematika Materi Pecahan Pada Siswa Kelas V SDN 188 Pekanbaru. Primary: Jurnal Pendidikan Guru Sekolah Dasar.

Heruman. (2013). Model Pembelajaran Matematika di Sekolah Dasar. Bandung: PT. Remaja Rosdakarya.

Hestuaji, Y. (2013). Pengaruh Media Kartu Domino Terhadap Pemahaman Konsep Pecahan. Journal FKIP UNS, Vol.3., No 1.

Indriana, D. (2011). Ragam Alat Bantu Media Pengajaran. Jogjakarta: DIVA Press

Irmawati, S. (2015). Pengaruh Pembelajaran Kooperatif Tipe Numbered Heads Together (THT) Berbasis Kartu Domino Terhadap Pemahaman Konsep Hitung Campuran. Jurnal Didaktika Dwija Indria(Solo), Vol.3, No. 4.

Kamsiyati, S. (2006). Pendidikan Matematika II. Surakarta: UNS Press

Lastri, A. S. (2019). pengaruh penggunaan media blok pecahan terhadap minat belajar. JIKAP PGSD: Jurnal Ilmiah Ilmu Kependidikan 3(1), 40-49.

Mansyur, L. d. (2007). Warna. Yogyakarta: Institut Seni Indonesia.

Mudjiman, H. (2007). Belajar Mandiri. Surakarta: LPP dan UNS Press

Mulyatiningsih, E. (2014). Metode Penelitian Terapan Bidang Pendidikan. Bandung: Alfabeta.

Putra, Z. H. (2019). Elementary Teachers' Knowledge on Fraction Multiplication: An Anthropological Theory of the Didactic Approach. Journal of Teaching and Learning in Elementary Education, 2(1), 47-52.

Putra, Z. H. (2019). Praxeological change and the density of rational numbers: The Case of pre-service teachers in Denmark and Indonesia. EURASIA Journal of Mathematics, Science and Technology Education, 15(5), em1711.

Putra, Z. H., Darmawijoyo, D., Putri, R. I. I., \& den Hertog, J. (2011). Supporting First Grade Students Learning Number Facts up to 10 Using a Parrot Game. Indonesian Mathematical Society Journal on Mathematics Education, 2(2), 163-172.

Rahayu. (2018). Penggunaan Alat Peraga dengan Pembelajaran Langsung dalam Meningkatkan Motivasi Mengajar Guru di SD Negeri 010 Pagaran Tapah Darussalam Kabupaten Rokan Hulu. Jurnal PAJAR (Pendidikan dan Pengajaran) Program Studi Pendidikan Guru Sekolah Dasar FKIP Universitas Riau. 2 ( 6): 1018-1022

Rendana, F. (2018) Pengembangan Media Pembelajaran IPA Berupa Kartu Domino Pada Materi Struktur dan Fungsi Tumbuhan Kelas IV SD/MI. Raden Intan Repository. 
Setiawan, Y. U. (2020). Pengembangan Kartu Domino Pecahan Sebagai Media Pembelajaran Matematika di Kelas IV Sekolah Dasar. Jurnal Keilmuan dan Kependidikan Dasar.

Siegler, R. S., \& Lortie-Forgues, H. (2017). Hard lessons: Why rational number arithmetic is so difficult for so many people. Current Directions in Psychological Science, 26(4), 346-351.

Sugiyono. (2013). Metode Penelitian Pendidikan (Pendekatan Kuantitatif, Kualitatif dan $R \& D)$.

Sugiyono. (2015). Metode Penelitian Pendidikan (Pendekatan Kuantitatif, Kualitatif dan $R \& D)$. Bandung: Alfabeta.

Winanda, W., Putra, Z. H., \& Zufriady, Z. (2020). Pengaruh Model Pembelajaran Kooperatif dengan Bantuan Media Tulang Napier terhadap Hasil Belajar Matematika Siswa Kelas III SD II Diniyah Pekanbaru. Tunjuk Ajar: Jurnal Penelitian Ilmu Pendidikan, 3(2), 250-260. 